\title{
Classroom Management and Students' Learning in Mathematics
}

\author{
Jeanilyn E. Tacadena, Ph.D \\ Program Head-BEED, UM Panabo College \\ DOI: https://dx.doi.org/10.47772/IJRISS.2021.5328
}

\begin{abstract}
This study aimed to determine the relationship of classroom management and students learning in mathematics among Grade VI students. Quantitative type of research was used employing a descriptive correlation method. The respondents were the selected grade VI students of 13 selected schools in Carmen District Davao del Norte. Two sets of questionnaire were used in a form of checklist on the extent of classroom management and teacher made test on the level of students learning in mathematics. Result showed that the extent of classroom management was practiced in most occasions and the level of students learning in mathematics was rarely manifested by students. This implies that there was a significant relationship between the extent of classroom management and the level of students' learning in mathematics of grade VI students in Carmen District Davao del Norte.
\end{abstract}

Keywords: education, classroom management, students learning in mathematics, grade six students, quantitative study, Philippines.

\section{INTRODUCTION}

\section{Background of the Study}

Ctudents' achievement in mathematics could be considered as one of the vital factors in their career development, successful college completion and employment. Nevertheless, many of the students from elementary through college level have experienced learning difficulties and illustrated poor mathematical performances (Haciomeroglu, 2014).

In addition, the classroom must become an atmosphere in which students can participate actively in rich, worthwhile mathematical practice in order to improve their mathematical capacities (Henningsen \& Stein, 1997). While a comprehensive understanding of mathematics and the learning of mathematics are essential for a successful math classroom, classroom management is one of the most important aspects that contribute to a positive learning atmosphere. Learning is almost impossible without a well-organized and disciplined classroom. It is important that a teacher starts each class with a well-thought-out lesson plan (Schroer, 2002).

The declining popularity of mathematics among students and poor mathematical performance of students are not only a national but also a global concern for the past years (Sangcap, 2010, Mayer, Tajika, \& Stanley, 1991\&PISA, 2003). According to the National Center for Education Statistics 2013, only 34 percent of fourth-graders in the U.S. performed at a proficient level in math and only 27 percent of U.S. eighth-graders performed at a proficient level in math.

In the Philippines, teachers struggle in helping children learn Mathematics. According to the presentation from the National Education Testing and Research Center entitled, NAT Overview and 2012 Test Results, the performance of the grade six learners in the context of mathematics is 66.47 MPS which is lesser than 8.53 percent out of the 75 MPS goal of Dep.Ed. It is also evident in Carmen District Davao del Norte, the result of the National Achievement Test (NAT) of Grade VI students decreased to $6.11 \%$ mean percentage score from 2014 to 2015. Specifically, in the context of mathematics it decreased $7.06 \%$ MPS from $78.02 \%$ result of 2014 to $70.96 \%$ result of 2015 .

The body of educational research literature which has come to be known as the effective schooling research identifies the practice of monitoring student learning as an essential component of high-quality education (Rutledge, Vogel \&Lampkin, 2012). Thus the low achievement of students in learning mathematics is still perceived as a continuous problem (Mushtaq, 2013). Anent to this, the conduct of this study was to determine whether the extent of classroom management affects students learning in mathematics among Grade VI students in Carmen District Davao del Norte. Hopefully, this study would contribute to the ongoing efforts in raising the academic achievements of students in learning mathematics.

\section{THEORETICAL FRAMEWORK AND CONCEPTUAL FRAMEWORK}

The following theories, concepts, and propositions were selected as bases where this study was anchored to:

This study is anchored on the theory of Vygotsky (1962) on Social Learning Theory which examined how social environments influence the learning process. He suggested that learning takes place through the interactions students have with their peers, teachers, and other experts. Consequently, teachers can create a learning environment that maximizes the learner's ability to interact with each other through discussion, collaboration, and feedback.

This is also supported by the preposition of Dias (2012) which states that classroom management requires establishing a positive learning environment and how this creates an impact 
to lives of every student, which includes awareness on student's emotional aspects, planning, time management and discipline.The mechanism by which teachers and schools establish and sustain acceptable student conduct in classroom settings. The aim of implementing classroom management techniques is to improve prosocial behavior and academic participation among students (Kratochwill,DeRoos, \&Blair, 2010).

Anent to this, it is conceptualized in this study that classroom management and students learning are related with each other. Figure 1. shows the conceptual paradigm of this study. The independent variable is the classroom management with five indicators such as: learning environment; students' emotional aspects; planning; time management; and discipline. The dependent variable is the students learning in mathematics. This simply explains that through the classroom management done by teachers it may affect students learning in mathematics.
Independent Variable

Classroom Management
*Learning environment
*Students' emotional aspect
*Planning
*Time management
*Discipline

\section{Research Objectives}

This study aimed to determine whether the extent of classroom management and level of students learning in mathematics.

Specifically, this study sought to answer the following questions:

1. What is the extent of Classroom Management in terms of:
1.1 learning environment;
1.2 students' emotional aspect;
1.3 planning;
1.4 time management; and
1.5 disciplines?

2. What is the level of students' learning in mathematics?

3. Is there a significant relationship between the classroom management and students' learning in mathematics among grade VI students in Carmen District Davao del Norte?

\section{Hypothesis}

The hypothesis tested at 0.05 level of significant, that there is no significant relationship between the classroom management and students' learning in mathematics among grade VI students in Carmen District Davao del Norte.

\section{RESEARCH DESIGN}

This is a quantitative study that employed a descriptive correlational method since the basic aim is to measure and describe the relationship between two variables by determining the magnitude and direction of such a relationship, if any exists (Pagano, 1998; Gravetter \&Wallnau, 2004) as mentioned by Esmalla (2010).

This design was adopted since the main problem of the study was to describe the relationship between classroom management practices and students learning in mathematics. Furthermore it was used to collect data to test the hypothesis through a researcher-made questionnaire for classroom management and a teacher-made questionnaire for students learning.

\section{Research Respondents}

The respondents of this study were the selected grade VI students of the different schools from Carmen District Davao del Norte. Using the Slovin's formula, out of one thousand two hundred forty six (1246) students the actual respondents are three hundred three (303) students. The respondents covered from the following schools namely; School 1 with (30) students; School 2 (17 )students; School 3 (10) students; School 4 (10) students; School 5 (51) students; School 6 (23) 
students; School 7 (13) students; School 8 (9) students; School 9 (9) students; School 10 (27) students; School 11 (11) students; School 12 (20) students and School 13 with (73) students.

The sampling technique used was simple random sampling. This simple random sampling is a sampling design that is selected from the number of items in the population in such a way that every possible combination of sample size items is equally likely to be the sample selected (Thompson, 2012).

\section{Statistical Treatment}

The response gathered from the questionnaire were tallied and tabulated in a master data sheet. Statistics needed to answer the sub-problems were as follows:

Mean. This is also known as the arithmetic mean, a value that helps summarizes an entire set of numbers. This was used to describe the extent of classroom management and students learning in mathematics. This was used to answer problems 1 and 2 .

Pearson $r$. The Pearson product-moment correlation commonly called Pearson $r$ is the most widely used measure of correlation. It is used when the variables are of the interval or ratio type of measurement. This was used to determine the linear relationship between extent of classroom management and students learning in mathematics. This was employed to answer problem number 3 .

\section{Research Instrument}

This study utilized two sets of questionnaire; a researchermade questionnaire for classroom management and a teachermade questionnaire for identifying students learning. The first set of questionnaire covered the classroom management such as: learning environment, students' emotional aspect, planning, time management and discipline. The second set of questionnaire identified the student learning in mathematics. The questionnaire contains (5) indicators for classroom management and (15) items for students learning in mathematics.

The questionnaires were presented to the adviser for corrections and suggestions for improvement, checked for content validity by the group of experts whose comments and suggestions were incorporated in the revision of the questionnaire. The questionnaires underwent for pilot test for reliability. The computation of classroom management reliability test using Cronbach alpha is 0.915 which means that it is in a high internal consistency. The computation of reliability on the level of student learning in mathematics using spearman brown is 0.7298 which obtained a high positive correlation. Thus, the whole test is reliable.

The Likert Scale was used whose weights were as follows: for the classroom management, 5 - Always, 4 - Often times, 3 Sometimes, 2 - Seldom, and 1 - Never. The parameter limits are shown below.

\begin{tabular}{|c|c|l|}
\hline $\begin{array}{c}\text { Parameter } \\
\text { Limits }\end{array}$ & $\begin{array}{c}\text { Descriptive } \\
\text { Equivalent }\end{array}$ & \multicolumn{1}{c|}{ Interpretation } \\
\hline $4.50-5.00$ & Always & $\begin{array}{l}\text { This means that the extent of classroom } \\
\text { management is practiced in all occasions. }\end{array}$ \\
\hline $3.50-4.49$ & Oftentimes & $\begin{array}{l}\text { This means that the extent of classroom } \\
\text { management is practiced in most ccasions. }\end{array}$ \\
\hline $2.50-3.49$ & Sometimes & $\begin{array}{l}\text { This means that the extent of classroom } \\
\text { management is practiced in some ccasions. }\end{array}$ \\
\hline $1.50-2.49$ & Seldom & $\begin{array}{l}\text { This means that the extent of classroom } \\
\text { management is rarely practiced. }\end{array}$ \\
\hline $1.00-1.49$ & Never & $\begin{array}{l}\text { This means that the extent of classroom } \\
\text { management is not observed. }\end{array}$ \\
\hline
\end{tabular}

For the level of students learning, this is anchored on the DepEd Order No. 8, s. 2015 on the learners' progress. This consists of grading scale, descriptive equivalent and interpretation.

\begin{tabular}{|c|c|l|}
\hline $\begin{array}{c}\text { Grading } \\
\text { Scale }\end{array}$ & $\begin{array}{c}\text { Descriptive } \\
\text { Equivalent }\end{array}$ & \multicolumn{1}{|c|}{ Interpretation } \\
\hline $90-100$ & Outstanding & $\begin{array}{l}\text { This means that the level of students } \\
\text { learning is highly manifested by } \\
\text { students in all areas. }\end{array}$ \\
\hline $85-89$ & $\begin{array}{c}\text { Very } \\
\text { Satisfactory }\end{array}$ & $\begin{array}{l}\text { This means that the level of students } \\
\text { learning is manifested by the students in } \\
\text { most of the areas. }\end{array}$ \\
\hline $80-84$ & Satisfactory & $\begin{array}{l}\text { This means that the level of students } \\
\text { learning manifested by the students in } \\
\text { some areas. }\end{array}$ \\
\hline $75-79$ & $\begin{array}{c}\text { Fairly } \\
\text { Satisfactory }\end{array}$ & $\begin{array}{l}\text { This means that the level of students } \\
\text { learning is rarely manifested by the } \\
\text { students. }\end{array}$ \\
\hline Below 75 & $\begin{array}{c}\text { Did not } \\
\text { meet the } \\
\text { expectation }\end{array}$ & $\begin{array}{l}\text { This means that the level of students } \\
\text { learning is never manifested by the } \\
\text { students. }\end{array}$ \\
\hline
\end{tabular}

\section{RESULTS}

\section{Extent of Classroom Management}

The extent of classroom management in terms of learning environment, students' emotional aspect, planning, time management, and discipline has an overall mean of 3.884 with a descriptive equivalent of Oftentimes. Supported by Nagler, et.al (2015) classroom management is designed to give students more opportunities to experience all of the things a teacher does to coordinate students, space, time, and resources so that they can learn and be able to reach their full potential, allowing them to form acceptable behavioral patterns. Moreover, teachers must be able to deal with unexpected events and use appropriate classroom management techniques to monitor student actions. Thus, all teachers should aim for effective classroom management and a positive classroom environment.

Shown in table 1, the indicators with their corresponding mean and descriptive equivalent. Discipline has the highest average weighted mean of 4.09 with a descriptive equivalent of Oftentimes. Classroom discipline taken as a conglomeration of all kinds of responses and manners that are 
exhibited by a great diversity of learners and the kind of discipline will depend on the students' personalities, levels of maturity and interest at the same time the managerial ability of teachers (Bilbao, et.al, 2006). Planning has an average weighted mean of 3.92 with a descriptive equivalent of Oftentimes. This is affirmed from the statement that effective teachers have classroom management plans, or scripts, ready before the first day of school. The lesson is also carefully planned and prepared such that all discussion are directed towards the achievement of its objective and the needed instructional tools and materials are readily available to ensure smooth conclusion of the lesson (Bilbao, et al. 2006).

Learning Environment has a mean of 3.89 with a descriptive equivalent of Oftentimes. As mentioned by Nagler, et. al (2015), the social, emotional, and physical environment of the classroom are all factors to consider. The atmosphere in the classroom has an effect on student development and behavior. A healthy classroom environment is one in which students feel comfortable, respected, welcomed, and supported in their learning. Also, students' emotional aspect has a mean of 3.88 with a descriptive equivalent of oftentimes. Few studies that connect positive emotions to achievement shows excitement, hope, and pride are positively correlated with academic selfefficacy, academic engagement and effort, and overall achievement among students (Pekrun et al., 2004\& Valiente, et.al, 2012).

On the other hand, time management has the lowest average weighted mean of 3.64 with a descriptive equivalent of Oftentimes. Pointed out by Bilbao et. al (2006), that how well an instructor uses time will affect how well he or she accomplishes and how well the students are aroused and sustained. Providing enough time for each learning activity, arranging tasks with corresponding time allotments, creating regular procedures, and assigning students the corresponding task and responsibilities can all help to save time and improve performance.

Table 1: Extent of Classroom Management in Mathematics among Grade VI Students

\begin{tabular}{|l|c|c|}
\hline \multicolumn{1}{|c|}{ Indicators } & Mean & $\begin{array}{l}\text { Descriptive } \\
\text { Equivalent }\end{array}$ \\
\hline A) Learning Environment & & \\
\hline $\begin{array}{l}\text { The teacher arranges students' } \\
\text { materials as well as the instructional } \\
\text { materials. }\end{array}$ & 3.73 & Oftentimes \\
\hline $\begin{array}{l}\text { The teacher cleans the board after } \\
\text { use. }\end{array}$ & 3.67 & Oftentimes \\
\hline $\begin{array}{l}\text { The teacher maintains cleanliness in } \\
\text { the classroom. }\end{array}$ & 4.02 & Oftentimes \\
\hline $\begin{array}{l}\text { The teacher ensures that classroom } \\
\text { is comfortable and well lighted. }\end{array}$ & 4.04 & Oftentimes \\
\hline $\begin{array}{l}\text { The teacher ensures wide space } \\
\text { during students' activity. }\end{array}$ & 3.99 & Oftentimes \\
\hline Mean & 3.89 & Oftentimes \\
\hline B) Students Emotional Aspect & 4.06 & Oftentimes \\
\hline The teacher is friendly. & 3.94 & Oftentimes \\
\hline $\begin{array}{l}\text { The teacher encourages class } \\
\text { participation. }\end{array}$ & 3.97 & Oftentimes \\
\hline The teacher respect students' views & \\
\hline
\end{tabular}

\begin{tabular}{|c|c|c|}
\hline and opinion. & & \\
\hline The teacher gives praises. & 3.81 & Oftentimes \\
\hline $\begin{array}{l}\text { The teacher gives games for fun and } \\
\text { enjoyment. }\end{array}$ & 3.59 & Oftentimes \\
\hline Mean & 3.88 & Oftentimes \\
\hline \multicolumn{3}{|l|}{ C) Planning } \\
\hline $\begin{array}{l}\text { The teacher introduces the } \\
\text { objectives before the class } \\
\text { discussion start. }\end{array}$ & 3.87 & Oftentimes \\
\hline $\begin{array}{l}\text { The teacher prepares the materials to } \\
\text { be used during the activity. }\end{array}$ & 4.04 & Oftentimes \\
\hline $\begin{array}{l}\text { The teacher connects lesson to } \\
\text { students' prior knowledge. }\end{array}$ & 3.92 & Oftentimes \\
\hline $\begin{array}{l}\text { The teacher provides positive } \\
\text { activities and direct classroom } \\
\text { instruction. }\end{array}$ & 3.97 & Oftentimes \\
\hline $\begin{array}{l}\text { The teacher involves creativity, } \\
\text { intellectual curiosity and higher } \\
\text { level thinking. }\end{array}$ & 3.83 & Oftentimes \\
\hline Mean & 3.92 & Oftentimes \\
\hline \multicolumn{3}{|l|}{ D) Time Management } \\
\hline $\begin{array}{l}\text { The teacher schedules activities with } \\
\text { corresponding time allotment. }\end{array}$ & 3.59 & Oftentimes \\
\hline $\begin{array}{l}\text { The teacher sets students } \\
\text { responsibility ahead of time. }\end{array}$ & 3.81 & Oftentimes \\
\hline $\begin{array}{l}\text { The teacher establishes daily } \\
\text { routines among students. }\end{array}$ & 3.62 & Oftentimes \\
\hline $\begin{array}{l}\text { The teacher provides enough time in } \\
\text { every activities. }\end{array}$ & 3.74 & Oftentimes \\
\hline $\begin{array}{l}\text { The teacher finishes his/her daily } \\
\text { lesson in one period. }\end{array}$ & 3.45 & Sometimes \\
\hline Mean & 3.64 & Oftentimes \\
\hline \multicolumn{3}{|l|}{ E) Discipline } \\
\hline $\begin{array}{l}\text { The teacher establishes rules and } \\
\text { policies among students. }\end{array}$ & 3.96 & Oftentimes \\
\hline $\begin{array}{l}\text { The teacher maintains classroom } \\
\text { control. }\end{array}$ & 4.09 & Oftentimes \\
\hline $\begin{array}{l}\text { The teacher treats students with the } \\
\text { same respect. }\end{array}$ & 4.18 & Oftentimes \\
\hline $\begin{array}{l}\text { The teacher assigns students to } \\
\text { different responsibilities. }\end{array}$ & 4.08 & Oftentimes \\
\hline $\begin{array}{l}\text { The teacher observes seating } \\
\text { arrangement. }\end{array}$ & 4.12 & Oftentimes \\
\hline Mean & 4.09 & Oftentimes \\
\hline Overall Mean & 3.884 & Oftentimes \\
\hline
\end{tabular}

Level of Students' Learning in Mathematics of Grade VI Students

Table 2 presents the level of students' learning in mathematics of grade VI students in Carmen District, Davao Del Norte. The class interval of below 75 got the highest frequency from 187 respondents or 61.72 percent with a descriptive equivalent of Did not Meet any Expectation. The class interval of 75-79 whose frequency is 68 or 22.44 percent with a descriptive equivalent of Fairly Satisfactory. The class interval of 85-89 got the lowest frequency of 7 respondents or 2.31 percent with a descriptive equivalent of Very Satisfactory.

Thus, the level of students' learning in mathematics has a mean of 75.68 with a descriptive equivalent of Fairly Satisfactory. This means that the level of students' learning in mathematics is rarely manifested. The result implies that students perform less in learning mathematics. 
Learning is not about how much you know, but how effectively you process or handle the information you receive. These are also mental mechanism that process incoming information and enable a person to successfully think, prioritize, plan, understand, visualize, remember, create useful associations and solve problems (Learning Rx-Cognitive Learning Style, 2015).Moreover, low-achieving students are required to receive information passively due to a lack of time and need more opportunities to learn mathematics at their own rate (Yeh, 2019).

Table 2: Level of Students' Learning in Mathematics of Grade VI Students in Carmen District Davao Del Norte

\begin{tabular}{|c|c|c|c|}
\hline $\begin{array}{c}\text { Class } \\
\text { Interval }(\mathrm{x})\end{array}$ & $\begin{array}{c}\text { Frequency } \\
(\mathrm{F})\end{array}$ & Percentage & $\begin{array}{c}\text { Descriptive } \\
\text { Equivalent }\end{array}$ \\
\hline $90-100$ & 20 & 6.60 & Outstanding \\
\hline $85-89$ & 7 & 2.31 & $\begin{array}{c}\text { Very } \\
\text { Satisfactory }\end{array}$ \\
\hline $80-84$ & 21 & 6.93 & Satisfactory \\
\hline $75-79$ & 187 & 22.44 & $\begin{array}{c}\text { Fairly } \\
\text { Satisfactory }\end{array}$ \\
\hline Below 75 & 303 & 100.00 & $\begin{array}{c}\text { Did not Meet } \\
\text { any } \\
\text { Expectation }\end{array}$ \\
\hline TOTAL & & 75.68 & $\begin{array}{c}\text { Fairly } \\
\text { Satisfactory }\end{array}$ \\
\hline MEAN & & & \\
\hline
\end{tabular}

Relationship between the Extents of Classroom Management and the Level of Students' Learning in Mathematics

Table 3 shows the significant relationship between the extent of classroom management and the level of students' learning in mathematics of grade VI students in Carmen District, Davao Del Norte.

The coefficient of correlation between the extent of classroom management and the level of students' learning in mathematics of grade VI students in Carmen District is 0.1049 . This indicates a negligible positive correlation. The computed $\mathrm{t}$ - value is 39.960 and the tabulated $\mathrm{t}$ - value is 4.3027 and $p$-value is 0.0006 . Thus, the computed $t$ - value is greater than the tabulated $\mathrm{t}-$ value and the $\mathrm{p}$-value is less than $\alpha=0.05$. Therefore, the null hypothesis is rejected and the alternative hypothesis is accepted. It means that there is significant relationship between the extent of classroom management and the level of students' learning in mathematics of grade VI students in Carmen District.

As noted in the coefficient of determination, it shows that $r^{2}$ has a value of 0.0110 or $1.10 \%$. This means that of the total respondents of the study, $1.10 \%$ of the variation in students' learning in mathematics could be attributed to the variation in the classroom management. The rest of $98.90 \%$ is chance variation. This is supported by Henningsen \& Stein, (1997) to develop students' abilities to do mathematics, the classroom must become a place where they can participate actively in rich, worthwhile mathematical activity.
Table 3: Relationship between the Extent of Classroom Management and the Level of Students' Learning in Mathematics

\begin{tabular}{|c|c|c|c|c|c|c|c|}
\hline \multirow[b]{2}{*}{ Variable } & \multirow{2}{*}{$\begin{array}{c}\text { Com } \\
\text { pute } \\
\text { d } \\
\text { R - } \\
\text { Valu } \\
\text { e }\end{array}$} & \multirow[b]{2}{*}{$\begin{array}{l}\text { Inter } \\
\text { Preta } \\
\text { tion }\end{array}$} & \multicolumn{2}{|c|}{$\begin{array}{l}\mathrm{t} \text { - value, } \\
\alpha=0.05\end{array}$} & \multirow[b]{2}{*}{$\begin{array}{l}\mathrm{P}- \\
\mathrm{Va} \\
\mathrm{lu} \\
\mathrm{e}\end{array}$} & \multirow{2}{*}{$\begin{array}{l}\text { Decis } \\
\text { ion } \\
\text { On } \\
\text { Ho: }\end{array}$} & \multirow{2}{*}{$\begin{array}{l}\text { Conclus } \\
\text { ion On } \\
\text { Relation } \\
\text { ship }\end{array}$} \\
\hline & & & $\begin{array}{c}\text { Co } \\
\text { mp } \\
\text { ute } \\
\text { d }\end{array}$ & $\begin{array}{l}\mathrm{Ta} \\
\mathrm{bu} \\
\text { lat } \\
\text { ed }\end{array}$ & & & \\
\hline \multicolumn{8}{|l|}{$\begin{array}{c}\text { Classroom } \\
\text { Manageme } \\
\text { nt } \\
\end{array}$} \\
\hline $\begin{array}{l}\text { Students' } \\
\text { Learning in } \\
\text { Mathemati } \\
\text { cs }\end{array}$ & $\begin{array}{c}0.10 \\
49\end{array}$ & $\begin{array}{c}\text { Negl } \\
\text { igibl } \\
\text { e } \\
\text { Posit } \\
\text { ive } \\
\text { Corr } \\
\text { elati } \\
\text { on }\end{array}$ & $\begin{array}{c}39 . \\
96 \\
0\end{array}$ & $\begin{array}{l}4 . \\
30 \\
27\end{array}$ & $\begin{array}{l}0 . \\
00 \\
06\end{array}$ & $\underset{t}{\text { Rejec }}$ & $\begin{array}{c}\text { Signific } \\
\text { ant }\end{array}$ \\
\hline$r^{2}$ & \multicolumn{4}{|c|}{$\begin{array}{l}\text { Coefficient of } \\
\text { Determination }\end{array}$} & & \multicolumn{2}{|c|}{0.0110} \\
\hline
\end{tabular}

\section{RECOMMENDATIONS}

After a thorough review of the findings and conclusions of the study, it is said that successful teachers build classrooms that are centered and caring, resulting in improved student learning. These teachers teach and practice rules and procedures with students, anticipate students' needs, have a plan in place to orient new students, and provide students with specific instructions. They use a limited number of rules to ensure classroom protection and constructive engagement, and they depend on routine.

Schools may employ interesting skills, challenging and relevant teaching methodologies and incorporategrouporiented activities which motivate the students to actively participate and manage their own learning. They may plan a procedure for the whole unit with a corresponding time allotment for each topic. They may allow flexibility in time to be spent in between but stick to the block of time when the unit is expected to be completed.

As a consequence, learning is a complex process that involves deciphering and linking new knowledge to what is already learned. Students must be willing participants in the learning process in order to learn well and profoundly. This normally means doing something, such as thinking, reading, debating, solving problems, or reflecting. Also, further studies on other factors that enhance students and some techniques in teaching emphasizing the learning of mathematics.

\section{REFERENCES}

[1] Bilbao, Corpuz, Llagas \&Salandanan (2006). The Teaching Profession: Lorimar Publishing, Inc. Quezon City

[2] Dias, M. (2012), Dealing with challenging situations in the classroom, Retrieved December 1, 2015 at 
http://saea.uottawa.ca/site/images/1-

TLSS/TA/documents/TAv2n1.pdf

[3] Haciomeroglu, G. (2014). Elementary Pre-Service Teachers' Mathematics Anxiety and Mathematics Teaching Anxiety. Retrieved November 30, $2015 \quad$ at http://www.cimt.plymouth.ac.uk/journal/haciomeroglu.pdf

[4] Henningsen, M. \& Stein, M.K. (1997). Mathematical Tasks and Student Cognition: Classroom-Based Factors That Support and Inhibit High-Level Mathematical Thinking and Reasoning. Retrieved November $30, \quad 2015 \quad$ at http://www.jstor.org/stable/749690?seq=1\#page_scan_tab_content

[5] Kratochwill, T., DeRoos, R. \&Blair, S. (2010). Classroom Management Module. Retrieved December 1, 2015. Classroom management module (apa.org)

[6] Learning Rx-Cognitive Learning Style, Retrieved December 03, 2015 at http://www.learningrx.com/cognitive-learning-styles.htm

[7] Mokoena, S. (2012). Effective Participative Management: Does It Affect Trust Levels of Stakeholders in Schools? Retrieved November 30, 2015. (PDF) Effective Participative Management: Does It Affect Trust Levels of Stakeholders in Schools? | Sello Mokoena - Academia.edu

[8] Mushtaq, F. (2013). Mathematics Achievements among High School Students In Afghanistan Gender Difference In Math Achievements. Retrieved November 30,2015. FULLTEXT01.pdf (diva-portal.org)
[9] Nagler,K.S. et. al (2015). Effective Classroom-Management \& Positive Teaching. Retrieved November 30, 2015. EJ1087130.pdf (ed.gov)

[10] Rutledge,S., Vogel, L. \&Lampkin, L. (2012) Identifying the Characteristics of Effective High Schools Retrieved November 30, 2015. ED538011.pdf

[11] Schoer,P.(2002).Philosophyof Classroom Management, Retrieved November

30,2015http://mste.illinois.edu/courses/ci302sp02/students/pschroe r/phil_classroom_management.htm

[12] Sangcap, P. (2010). Mathematics-related Beliefs of Filipino College Students: Factors Affecting Mathematics and Problem Solving Performance, Retrieved November 30, 2015. Mathematics-related Beliefs of Filipino College Students: Factors Affecting Mathematics and Problem Solving Performance (sciencedirectassets.com)

[13] Thompson, S. K. (2012). Sampling. Wiley, 3 edition. Retrieved December 9, 2015. Sampling, 3rd Edition | Wiley

[14] Valiente, C. et. al (2012). Linking Students' Emotions and Academic Achievement: When and Why Emotions Matter. Retrieved December 9, 2015. Linking Students' Emotions and Academic Achievement: When and Why Emotions Matter (nih.gov)

[15] Yeh, C. et. al (2019). Enhancing achievement and interest in mathematics learning through Math-Island. Enhancing achievement and interest in mathematics learning through MathIsland | Research and Practice in Technology Enhanced Learning | Full Text (springeropen.com) 